\title{
ANALISIS FAKTOR RISIKO PERILAKU DAN LINGKUNGAN TERHADAP KELUHAN NYERI KEPALA PADA PELAJAR SEKOLAH MENENGAH ATAS (SMA) DI KOTA MALANG (STUDI KASUS DI SMAN 2 KOTA MALANG).
}

\author{
Febri Endra Budi Setyawan', Karis Akmal Hussin ${ }^{2}$ \\ ${ }^{1}$ Laboratorium Ilmu Kedokteran Keluarga, Industri dan KeIslaman \\ ${ }^{2}$ Fakultas Kedokteran, Universitas Muhammadiyah, Malang
}

\author{
Email : Febri_dirgantara@yahoo.co.id
}

\begin{abstract}
ABSTRAK
Latar belakang: Nyeri kepala adalah salah satu keluhan paling umum dikeluhkan oleh pasien saat ke dokter. Nyeri kepala dapat dipengaruhi dari psikobiologis, perilaku, lingkungan dan pelayanan kesehatan. Nyeri kepala juga sering dikeluhkan oleh pelajar tingkat sekolah menengah atas (SMA).

Tujuan: Untuk menganalisis faktor risiko perilaku dan lingkungan (psikologi, sosial, budaya) terhadap keluhan nyeri kepala pada pelajar SMA di Kota Malang (studi kasus di SMAN 2 Kota Malang).

Metode: Penelitian ini adalah penelitian analitik observasional dengan pendekatan cross sectional dengan subyek penelitian siswa dan siswi SMAN 2 Kota Malang. Pelaksanaan pada bulan Oktober-November 2017. Subyek penelitian 291 orang dengan stratified simple random sampling. Pengumpulan data dengan wawancara. Uji hipotesis menggunakan uji chi square, lambda dan regresi logistik.

Hasil dan Diskusi: Tidak terdapat perbedaaan kejadian nyeri kepala berdasarkan tingkatan kelas $(\mathrm{p}=0,886)$. Faktor sarapan merupakan faktor terbesar yang berpengaruh dengan $r=0,606$ dan $P R=3,5$. Fungsi sarapan bagi tubuh adalah sebagai pemberi pasokan energi dan sumber tenaga untuk melakukan segala kegiatan, pertumbuhan dan pemeliharaan jaringan tubuh serta mengatur proses metabolisme tubuh. Faktor lain yang berpengaruh terhadap kejadian nyeri kepala adalah perlakuan yang tidak adil, konflik keluarga, tuntutan orangtua, beban pelajaran, keteraturan makan, penggunaan gadget dan pola tidur.

Kesimpulan: Faktor risiko yang berpengaruh menyebabkan timbulnya nyeri kepala pada pelajar SMAN 2 Kota Malang, yaitu: konflik dalam keluarga, tuntutan dari orangtua, beban pelajaran, sarapan, keteraturan pola makan, merokok, minum kopi, sikap yang terburu-buru, penggunaan earphone, penggunaan gadget dan tidur larut malam.
\end{abstract}

Kata-kata kunci : Faktor risiko, Perilaku, Lingkungan, Nyeri kepala

\section{ABSTRACT}

Background: Headache is one of the most common complaints complained by patients when they go to a doctor. Headaches can be affected from psychobiological, behavioral, environmental and health services. Headache is also often complained by high school students (bigh school).

Objective: To analyze behavioral and environmental risk, factors (psychology, social, culture) on headache complaints on high school students in Malang (case study in SMAN 2 Malang).

Method: This research is an observational analytic research with cross sectional approach with research subjects of students and SMAN 2 Malang. Implementation in October-November 2017. Research subjects 291 people with stratified simple random sampling. Data collection by interview. Hypothesis test using chi square test, lambda and logistic regression.

Results and Discussion: There was no difference in the incidence of headache based on the grade level $(p=0.886)$. The breakfast factor is the biggest factor that affects $r=0.606$ and $P R=3.5$. Breakfast function for the body is as a provider of energy and energy sources to do all activities, growth and maintenance of body tissues and regulate the body's metabolic processes. Other factors that affect the incidence of headache is the unfair treatment, family conflicts, parent demands, burden lessons, eating regularity, use of gadgets and sleep patterns. 
Conclusion: The risk factors that influence the occurrence of beadache in students SMAN 2 Malang, namely: the conflict in the family, the demands of parents, the burden of lessons, breakfast, regular eating patterns, smoking, drinking coffee, hasty attitude, the use of earphones, use of gadgets and sleep late at night.

Keywords: Risk, factors, Behavior, Environment, Headache

\section{PENDAHULUAN}

Nyeri kepala timbul sebagai hasil perangsangan terhadap bagian tubuh di wilayah kepala dan leher yang peka terhadap nyeri (Akbar, 2010). Sebagian besar orang pernah mengalami nyeri kepala (sefalgi) pada sepanjang hidupnya, terbukti dari hasil penelitian population base di Singapore (Ho, 2002). Hampir 90\% nyeri kepala benigna (tidak membahayakan). Meskipun demikian, dokter dihadapkan dengan tugas penting dalam memilah nyeri kepala yang benigna dan mengancam nyawa. Banyaknya penyakit yang disertai keluhan nyeri kepala membuat dokter perlu melakukan pendekatan yang fokus dan sistematis agar mendapatkan diagnosis nyeri kepala dengan tepat. Diagnosis yang tepat akan dapat mengantarkan pada pengobatan yang tepat (Grosberg, 2013).

Kejadian nyeri kepala tidak hanya dipengaruhi oleh satu faktor. H.L Blum menjelaskan terdapat 4 (empat) faktor utama yang mempengaruhi derajat kesehatan. Ke-empat faktor tersebut terdiri dari faktor genetik (keturunan), faktor perilaku/gaya hidup (life style), faktor lingkungan dan faktor pelayanan kesehatan. Ke-empat faktor tersebut saling berinteraksi yang mempengaruhi kesehatan perorangan dan derajat kesehatan masyarakat. Faktor risiko lingkungan memiliki pengaruh dan peranan terbesar diikuti perilaku, fasilitas kesehatan dan keturunan.

Keluhan nyeri kepala juga sering dikeluhkan oleh siswa atau pelajar tingkat sekolah menengah atas (SMA). Berdasarkan uraian diatas, maka peneliti bermaksud melakukan analisis faktor risiko perilaku dan lingkungan terhadap keluhan nyeri kepala pada pelajar SMA di Kota Malang (studi kasus di SMAN 2 Kota Malang).

\section{METODE PENELITIAN}

\section{Desain Penelitian}

Penelitian ini merupakan penelitian observasional analitik dengan pendekatan cross sectional. Penelitian dilakukan di SMAN 2 Kota Malang pada bulan Oktober-November 2017.

\section{Sampel Penelitian}

Populasi dan sampel penelitian ini adalah siawa dan siswi SMAN 2 Kota Malang. Penentuan besar sampel menggunakan rumus Slovin dengan teknik pengambilan sampel menggunakan stratified simple random sampling, dimana didapatkan jumlah sampel dalam sebanyak 291 orang. Sampel terpilih adalah siswa dan siswi SMAN 2 Kota Malang yang tercatat aktif pada tahun ajaran 2017/2018.

\section{Analisis Data Penelitian}

Pada penelitian ini, data diperoleh dari hasil wawancara dengan acuan kuesioner yang dilakukan pada siswa dan siswi SMAN 2 Kota Malang. Data yang diperoleh dari jawaban responden akan diolah, ditabulasikan, disajikan dalam bentuk tabel dan diuji dengan chi square, lambda dan regresi logistik

\section{HASIL}

Data yang diperoleh dari penlitian ini ditabulasikan dalam bentuk tabel distribusi frekuensi responden. 
Tabel 1 Distribusi Kelompok Responden Berdasarkan Faktor Risiko

\begin{tabular}{|l|c|c|c|c|c|c|}
\hline \multirow{2}{*}{ Uraian } & \multicolumn{2}{|c|}{ Kelas X } & \multicolumn{2}{c|}{ Kelas XI } & \multicolumn{2}{c|}{ Kelas XII } \\
\cline { 2 - 7 } & Ya & Tidak & Ya & Tidak & Ya & Tidak \\
\cline { 2 - 7 } & $\mathrm{n}(\%)$ & $\mathrm{n}(\%)$ & $\mathrm{n}(\%)$ & $\mathrm{n}(\%)$ & $\mathrm{n}(\%)$ & $\mathrm{n}(\%)$ \\
\hline Keluhan Nyeri Kepala & $69(69,7)$ & $30(30,3)$ & $68(72,3)$ & $26(27,7)$ & $68(69,4)$ & $30(30,6)$ \\
\hline Konflik Dalam Keluarga & $60(60,6)$ & $39(39,4)$ & $63(67)$ & $31(33)$ & $71(72,4)$ & $27(27,6)$ \\
\hline $\begin{array}{l}\text { Tuntutan Nilai Bagus Dari } \\
\text { Orangtua }\end{array}$ & $60(60,6)$ & $39(39,4)$ & $63(67)$ & $31(33)$ & $68(69,4)$ & $30(30,6)$ \\
\hline Beban Pelajaran & $55(55,6)$ & $44(44,4)$ & $63(67)$ & $31(33)$ & $68(69,4)$ & $30(30,6)$ \\
\hline Perlakuan Tidak Adil & $53(53,5)$ & $46(46,5)$ & $59(62,8)$ & $35(37,2)$ & $66(67,3)$ & $32(32,7)$ \\
\hline Pengalaman Buruk & $53(53,5)$ & $46(46,5)$ & $58(61,7)$ & $36(38,3)$ & $66(67,3)$ & $32(32,7)$ \\
\hline Perasaan Tidak Puas & $54(54,5)$ & $45(45,5)$ & $58(61,7)$ & $36(38,3)$ & $67(68,4)$ & $31(31,5)$ \\
\hline Sarapan & $63(63,6)$ & $36(36,4)$ & $63(67)$ & $31(33)$ & $68(69,4)$ & $30(30,6)$ \\
\hline Keteraturan Makan & $60(60,6)$ & $39(39,4)$ & $63(67)$ & $31(33)$ & $71(72,4)$ & $27(27,6)$ \\
\hline Merokok & $54(54,5)$ & $45(45,5)$ & $63(67)$ & $31(33)$ & $68(69,4)$ & $30(30,6)$ \\
\hline Minum Kopi & $56(56,6)$ & $43(43,4)$ & $62(66)$ & $32(32)$ & $66(67,3)$ & $32(32,7)$ \\
\hline Sikap Terburu & $47(47,5)$ & $52(52,5)$ & $63(67)$ & $31(33)$ & $66(67,3)$ & $32(32,7)$ \\
\hline Pengguanaan Earphone & $54(54,5)$ & $45(45,5)$ & $60(63,8)$ & $34(36,2)$ & $64(65,3)$ & $34(34,7)$ \\
\hline Penggunaan Layar Gadged & $53(53,5)$ & $46(46,5)$ & $63(67)$ & $31(33)$ & $68(69,4)$ & $30(30,6)$ \\
\hline Aktifitas Fisik Berlebih & $48(48,5)$ & $51(51,5)$ & $68(72,3)$ & $26(27,7)$ & $70(71,4)$ & $28(28,6)$ \\
\hline Pola Tidur Larut & $57(57,6)$ & $42(42,4)$ & $62(66)$ & $32(34)$ & $68(69,4)$ & $30(30,6)$ \\
\hline
\end{tabular}

Tabel 2 Analisis Korelasi Lambda Faktor Risiko Perilaku dan Lingkungan Terhadap Keluhan Nyeri Kepala Siswa dan siswi SMAN 2 Kota Malang

\begin{tabular}{|l|c|c|c|}
\hline \multicolumn{1}{|c|}{ Fak tor Risiko } & Signifikansi & Nilai Korelasi & Kekuatan Korelasi \\
\hline Konflik Dalam Keluarga & 0,000 & 0,547 & Sedang \\
\hline Tuntutan Nilai Bagus Dari Orangtua & 0,000 & 0,558 & Sedang \\
\hline Beban Pelajaran & 0,000 & 0,500 & Sedang \\
\hline Perlakuan Tidak Adil & 0,108 & 0,198 & - \\
\hline Pengalaman Buruk & 0,260 & 0140 & - \\
\hline Perasaan Tidak Puas & 0,185 & 0,163 & - \\
\hline Sarapan & 0,000 & 0,606 & Kuat \\
\hline Keteraturan Makan & 0,000 & 0,477 & Sedang \\
\hline Merokok & 0,011 & 0,302 & Lemah \\
\hline Minum Kopi & 0,001 & 0,384 & Lemah \\
\hline Sikap Terburu & 0,002 & 0,384 & Lemah \\
\hline Pengguanaan Earphone & 0,300 & 0,128 & - \\
\hline Penggunaan Layar Gadged & 0,000 & 0,453 & Sedang \\
\hline Aktifitas Fisik Berlebih & 0,062 & 0,221 & - \\
\hline Pola Tidur Larut & 0,000 & 0,488 & Sedang \\
\hline
\end{tabular}

Tabel 3 Uji Komparasi Chi Square Tingkatan Kelas Terhadap Keluhan Nyeri Kepala Siswa dan siswi SMAN 2 Kota Malang

\begin{tabular}{|c|c|c|c|}
\hline Uji Hipotesis & Nilai & $\mathrm{df}$ & Signifik ansi \\
\hline Chi-Square &, $241^{\mathrm{a}}$ & 2 &, 886 \\
\hline Rasio Likelihood &, 243 & 2 &, 886 \\
\hline Asosiasi Linear-by-Linear &, 002 & 1 &, 963 \\
\hline
\end{tabular}


Tabel 4 Persamaan Regresi Logistik

\begin{tabular}{|l|c|c|c|}
\hline \multicolumn{1}{|c|}{ Fak tor risiko } & B & Wald & Signifikansi \\
\hline Konflik Dalam Keluarga & $-1,465$ & 0,672 & 0,412 \\
\hline Tuntutan Nilai Bagus Dari Orangtua & $-0,056$ & 0,001 & 0,971 \\
\hline Beban Pelajaran & $-19,928$ & 0,000 & 0,999 \\
\hline Perlakuan Tidak Adil & $-18,794$ & 0,000 & 0,999 \\
\hline Pengalaman Buruk & 56,842 & 0,000 & 0,999 \\
\hline Perasaan Tidak Puas & $-36,759$ & 0,000 & 0,999 \\
\hline Sarapan & $-3,365$ & 7,061 & 0,008 \\
\hline Keteraturan Makan & 0,021 &, 000 & 0,986 \\
\hline Merokok & 0,892 & 1,128 & 0,288 \\
\hline Minum Kopi & $-0,708$ & 1,218 & 0,270 \\
\hline Sikap Terburu & 0,535 & 0,138 & 0,710 \\
\hline Pengguanaan Earphone & $-1,033$ & 1,272 & 0,259 \\
\hline Penggunaan Lavar Gadged & 18,666 & 0,000 & 0,999 \\
\hline Aktifitas Fisik Berlebih &, 702 & 1,032 & 0,310 \\
\hline Pola Tidur Larut &, 549 &, 073 & 0,786 \\
\hline Konstanta & 1,157 & 15,821 & 0,000 \\
\hline
\end{tabular}

Berdasarkan data pada tabel 1 diketahui bahwa di semua tingkatan kelas sebagian besar (69,4\%-72,3\%) pernah mengeluh sakit kepala dalam kurun waktu 3 bulan terakhir. Kota Malang memiliki nilai $\mathrm{p}=0,886$. Berdasarkan pada tabel 2 diketahui bahwa terdapat beberapa faktor risiko yang memiliki nilai $\mathrm{p}>0,05$ yaitu faktor perlakuan yang tidak adil, faktor pengalaman buruk sebelumnya, faktor perasaan tidak puas terhadap pencapaian nilai, faktor penggunaan earphone dan faktor aktivitas fisik yang berlebihan. Berdasarkan pada tabel 5.4 dapat ditunjukkan bahwa faktor risiko yang memiliki nilai korelasi paling tinggi yaitu sarapan pagi yang memiliki $r=0,606$. Berdasarkan dari tabel 3

dapat diketahui hubungan tingkatan kelas terhadap terjadinya keluhan nyeri kepala pada siswa dan siswi SMAN 2.

Pada tabel 4, apabila seluruh faktor risiko pada penelitian ini dialami, maka diketahui bahwa hanya faktor sarapan yang memiliki pengaruh terjadinya keluhan nyeri kepala pada siswa dan siswi SMAN 2 Kota Malang dengan pengaruh (PR) sebesar 0,035 sehingga model persamaan yang dibentuk adalah $\mathrm{Y}=1,157+(-3,365)$ sarapan.

\section{PEMBAHASAN}

Nyeri kepala adalah kondisi umum yang selalu mengganggu. Gangguan yang diakibatkan oleh nyeri kepala mulai dari yang ringan seperti gangguan fungsional sampai yang berat (mengancam nyawa). Nyeri kepala merupakan masalah kesehatan yang sering timbul pada remaja. Nyeri kepala primer (NKP) yang berulang merupakan faktor risiko terjadi nyeri kepala kronik di kemudian hari. Berbagai jenis NKP menurunkan kualitas hidup remaja dan merupakan penyebab utama ketidakhadiran siswa di sekolah.

Pada anak sekolah, bentuk yang paling umum adalah sakit kepala primer, yang didefinisikan sebagai sakit kepala yang tidak terkait dengan gangguan mendasar. Frekuensi rata-rata sakit kepala (prevalensi 1 bulan) pada 50 populasi menunjukkan $58,4 \%$ mengalami sakit kepala (Straube, 2013). Keluhan nyeri kepala pada anak, kategori migren dan tension-type headache (TTH) menunjukkan prevalensi paling tinggi. Prevalensi migren adalah $3 \%$ pada anak pra sekolah, 4-11\% pada anak usia sekolah dasar, dan 8-23\% pada anak sekolah menengah, sedangkan prevalensi T'TH adalah 3078\% (IDAI, 2013). Kemungkinan sumber nyeri pada T'TH adalah adanya keterlibatan otot yang melekat pada tulang tengkorak, patofisiologinya sebagian besar tidak diketahui. Asal nyeri pada TTH dikaitkan dengan meningkatnya kontraksi dan 
iskemia otot kepala dan leher (Jan, 2007). Nyeri kepala tegang otot biasanya timbul menjelang siang dan sore dan berkurang setelah istirahat.

Kebiasaan makan pagi sangat penting bagi tubuh karena lambung akan terisi kembali setelah 8-10 jam kosong serta kadar gula akan menurun sehingga pasokan energi ke otak kurang ketika meninggalkan makan pagi. Kondisi tersebut berkaitan dengan penggunaan glukosa sebagai sumber energi (Prabowo, 2011).

Leane dalam Istianah (2008), anak yang tidak sarapan akan mengalami gejala rendahnya kadar gula (hipoglikeni), dengan gejala antara lain, sakit kepala, sepat lelah dan mengantuk. Sarapan adalah aktifitas makan pada pagi hari siantara pukul 06.0009.00 dengan jumlah yang dimakan kurang lebih $1 / 3$ dari jumlah kebutuhan makanan dalam satu hari. Fungsi sarapan bagi tubuh adalah sebagai pemberi pasokan energi dan sumber tenaga untuk melakukan segala kegiatan, pertumbuhan dan pemeliharaan jaringan tubuh serta mengatur proses metabolisme tubuh (Sunita, 2005).

Faktor lain yang cukup besar memiliki pengaruh terhadap keluhan nyeri kepala pada penelitian ini adalah adanya tuntutan dari orangtua untuk mendapatkan nilai bagus dalam pelajaran. Hal ini dapat menyebabkan siswa dan siswi mengalami stres. Lin (2014) menyatakan bahwa stres yang jumlahnya begitu banyak bisa membahayakan kepada setiap orang, termasuk siswa. Stres adalah tekanan psikis akibat adanya tuntutan dalam diri dan lingkungan, misalnya tuntutan belajar menjelang ujian, menghadapi masalah keluarga atau hubungan antar teman (Rathus, 2002). Hal tersebut berarti stres kerja dapat mempengaruhi kejadian nyeri kepala, sesuai dengan teori Jensen (2001) yang mengatakan bahwa rangsangan stressor salah satunya berupa stres kerja diterima oleh nosiseptor (reseptor nyeri) dan pada akhirnya di transmisi serta modulasi nyeri pada batang otak (Goal, 2016). Pada penelitian L. Kelman (2007) juga menyebutkan bahwa seseorang yang mengalami stres memiliki risiko yang lebih besar terjadi migrain, yaitu sebesar 79,7\%.

Beban pelajaran yang cukup berat ini akan mempengaruhi pola tidur dari siswa dan siswi SMAN 2 Kota Malang. Hal ini dapat dilihat pada tabel 5.2 bahwa 64,3\% siswa dan siswi SMAN 2 Kota Malang tidur setelah pukul 22.00 WIB.
Kebiasaan tidur larut malam ini ini ternyata juga menjadi faktor risiko yang cukup berpengaruh terhadap terjadinya keluhan nyeri kepala. Faktorfaktor psikis dapat menjadi pemicu NKP kronik dan gangguan tidur karena berbagai penelitian yang dilakukan telah membuktikan adanya hubungan kedua kondisi tersebut dengan kecemasan dan depresi. Kecemasan, depresi dan faktor psikososial telah lama diketahui sebagai faktor-faktor pencetus TTH (Grieser, 2010; Odegard dkk., 2011).

Pada remaja terdapat perubahan besar dalam pola bangun-tidur meliputi durasi tidur berkurang, waktu tidur tertunda serta perbedaan pola tidur pada hari kerja dan akhir pekan sehingga kualitas tidur remaja cenderung berkurang (Mindell, 2003). Pada beberapa dekade terakhir, penelitian epidemiologi menunjukkan bahwa jumlah remaja yang mengalami gangguan tidur semakin meningkat. Ohida dkk (2004) menunjukkan prevalensi gangguan tidur pada siswa sekolah menengah bervariasi yaitu 15,3\%-39,2\%. Sedangkan menurut hasil penelitian Bruni dkk. (1996), prevalensi gangguan tidur pada remaja adalah 73,4\%. Menurut Bellini dkk. (2013) melaporkan berbagai gangguan psikiatri yang merupakan komorbidi dari suatu NKP (Nyeri Kepala Primer) kronik pada remaja dan diperkirakan dapat menjelaskan bagaimana hubungan antara status psikiatri penderita dengan memberatnya gejala NKP. Kualitas tidur yang buruk dapat mengubah proses modulasi nyeri sehingga menjadi lebih peka terhadap nyeri. Hipotalamus diperkirakan sebagai tempat utama dimulainya disfungsi neurobiologi. Hipotalamus berhubungan dengan batang otak dalam proses regulasi nyeri dan tidur. Hipotalamus posterior mewakili pusat pengaturan utama fungsi otonom sentral, sehingga jika terjadi perubahan pada fungsi homeostatik akan menyebabkan perubahan pada kontrol nyeri. Hipotalamus posterior juga memiliki koneksi yang penting dengan sistem modulasi nyeri, menerima input dari korteks singulatus anterior, nuklues septal lateral, nukleus preoptik, nuklues ventromedial dan lateral talamus serta PAG. Hipotalamus posterior kemudian memproyeksikan serabutnya ke subtalamus, amigdala, dasar dari otak depan, regio limbik dan nukleus trigeminal kaudalis. Hipotalamus dapat menjelaskan hubungan neuroanatomi antara timbulnya NKP dengan gangguan tidur (Alstadhaug, 2008). 
Soderqvist (2008) mengemukakan bahwa penggunaan telepon genggam pada remaja di Swedia dengan rentang usia 15-19 tahun lebih sering mengeluhkan nyeri kepala, kelelahan, stres, cemas, susah berkonsentrasi dan gangguan tidur. Prevalensi penggunaan telepon genggam di Singapura dari hasil penelitian didapatkan bahwa 808 laki-laki dan perempuan antara berusia 12-70 tahun yang tinggal dalam satu komunitas sekitar $44,8 \%$ diantaranya menggunakan telepon genggam dan gejala yang umumnya dialami oleh para pengguna telepon genggam adalah nyeri kepala dan ada peningkatan yang signifikan antara prevalensi nyeri kepala dengan peningkatan durasi penggunaannya (dalam menit per hari) (Chia et al., 2000).

\section{KESIMPULAN}

Faktor risiko yang berpengaruh menyebabkan timbulnya nyeri kepala pada siswa siswi SMAN 2 Kota Malang, yaitu: adanya konflik dalam keluarga, tuntutan dari orang tua, beban pelajaran, kebiasaan sarapan, keteraturan pola makan, kebiasaan merokok, kebiasaan minum kopi, sikap yang terburu-buru, penggunaan earphone, penggunaan gadget dan pola tidur larut malam. Keluhan nyeri kepala ini dialami oleh $70,5 \%$ siswa dan siswi SMAN 2 Kota Malang.

\section{DAFTAR PUSTAKA}

Akbar M, 2010, Nyeri Kepala, Bagian Ilmu Penyakit Saraf Fakultas Kedokteran Universitas Hasanuddin, Makassar.

Alstadhaug K, 2009, Migraine and Hypothalamus, Cephalalgia;29(8), pp:809-817.

Bellini B, et al. Headache and Comorbidity in Children and Adolescents, Journal Headache Pain, Vol 14(1), pp:79-83.

Blum HL, 1981, Planning for Health. Human Sciences Press, 2nd edition, New York.

Chia SE, Chia HP, Tan JS,2000, Prevalence of Headache Among Handheld Cellular Telephone Users in Singapore: a Community Study, Environ Health Perspect, Vol.108, pp:1059-1062.

Goal NTL, 2016, Teori Stres: Stimulus, Respon dan Transaksional, Buletin Psikologi,Vol 24 No 1, hal: 1-11, DOI:10.22146/bpsi.11224.
Grieser EA, 2010, The Relationship Between Sleep Variables and Headache, Dissertation Prepared for The Degree of Doctor of Philosophy, University of North Texas, USA.

Grosberg BM, Friedman BW, Solomon S, 2013, Approach to the Patient with Headache in Robbins MS, Grosberg BM, Lipton RB (Eds), Headache:Hong Kong, Wiley Blackwell, p: 16-25.

Ho KH, Ong BKC, 2002, A Community Based Study of Headache Diagnosis and Prevalence in Singapore, Journal Cephalgia, Vol.23, pp: 6-13.

Jan, M., 2007. Updated Overview of Pediactric Headache and Migren, Saudi, Men, j.

Lin SH, \& Huang YC, 2014, Life Stress and Academic Burnout, Active Learning In Higher Education,Vol.15(1), pp: 77-90, DOI: $10.1177 / 1469787413514651$.

Mindell J, Owens J, 2003, A Sleep in The Pediatric Practice, In: Mindell J, editor. A Clinical Guide to Pediatric Sleep: Diagnosis and Management of Sleep Problems. Lippincott: Williams\&Wilkins, pp:1-10.

Odegard, SS, Sand, T, Engstrom, M, Stovner, LJ, Zwart, JA, Hagen, K, 2011, The Long-Term Effect of Insomnia on Primary Headaches: $A$ Prospective Population-Based Cohort Study (HUNT-2 and HUNT-3), The Journal of Headache, Vol.51 Issue 4, DOI: 10.1111/ j.1526-4610.2011.01859.x, pp: 570-580.

Ohida, T., Osaki, Y., Doi, Y., Tanihata, T., Minowa, M., Suzuki, K, (et al),. 2004, An Epidemiologic Study of Self Reported Sleep Problems among Japanese Adolescen Sleep, Journal Cephalgia, Vol.27, pp: 978-985.

Prabowo YSB, 2011, Hubungan antara Kebiasaan Sarapan Pagi dengan Indeks Prestasi Kumulatif (IPK) Mahasiswa Tingkat III Fakultas Kedokteran UPN “Veteran” Jakarta Tahun Ajaran 2010-2011, Jakarta.

Soderqvist F, Carlberg M, Hardell L, 2008, Use of Wireless Telephones and Selfreported Health Symptoms: A Population-Based Study Among Swedish Adolescents Aged 15-19 Years, Environ Health, Vol.7, p: 18.

Rathus S, Nevid J, 2002, Psychology and The Challenge of Life : Adjustment in The New Millennium, 
76 VOLUME 14 NOMOR 2 TAHUN 2018

Eight edition, Danver, John Wiley\&Sons, Inc.

Straube A, Heinen F, Ebinger F, Kries RV, 2013, Review Article: Headache in School Children: Prevalence and Risk Factors, Deutsches Arzteblatt International, München, Germany, hal. 811816, diunduh tanggal 18 Juli 2017, (https:// www.ncbi.nlm.nih.gov/pmc/articles/ PMC3865491/pdf/Dtsch Arztebl Int 110-0811.pdf).

Sunita A, 2005, Prinsip Dasar Ilmu Gizi, Jakarta: Gramedia Pustaka Utama, Cet V, hal 8. 